\author{
ACTA MYCOLOGICA \\ Vol. 43 (1): 41-48 \\ 2008
}

\title{
Enzymatic activity of Phlebiopsis gigantea isolates
}

\author{
ANNA ŻÓŁCIAK ${ }^{1}$, TERESA ANNA KORNIŁLOWICZ-KOWALSKA², \\ ZBIGNIEW SIEROTA $^{1}$ and HELENA IGLIK ${ }^{2}$ \\ ${ }^{1}$ Forest Research Institute, Sękocin Stary, Braci Leśnej 3 \\ PL-05-090 Raszyn, A.Zolciak@ibles.waw.pl \\ ${ }^{2}$ University of Life Sciences in Lublin, Leszczyńskiego 7, PL-20-069 Lublin
}

Żółciak A., Korniłłowicz-Kowalska T. A., Sierota Z., Iglik H.: Enzymatic activity of Phlebiopsis gigantea isolates. Acta Mycol. 43(1): 41-48, 2008.

Initial experiment was made in order to test wood-decomposing fungus Phlebiopsis gigantea for enzymatic activity. Laccase, peroxidase, cellulase, phosphatase, dehydrogenase were marked using different methods for $P$. gigantea isolates growing on Scots pine wood.

Key words: Phlebiopsis gigantea, laccase, peroxidase, cellulase, phosphatase, dehydrogenase

\section{INTRODUCTION}

Studies on biology and application possibilities of Phlebiopsis gigantea (Fr.: Fr.) Jülich [=Phanerochaete gigantea (Fr.: Fr.) Rattan et al.] with the aim of control of parasite infections caused in Scots pine and Norway spruce stands by Heterobasidion annosum sensu lato were initiated back in the fifties and the sixties (Rishbeth 1951, 1959, 1963). Due to remaining threat of $H$. annosum on roots, these studies are being continued in the U.K. and have been commenced and conducted in other countries too, such as Finland, Poland, Sweden and Italy (Korhonen et al. 1994; Sierota 1995; Nicolotti et al. 1999; Pratt et al. 2000; Westlund, Nohrstedt 2000; Lakomy 2001; Pettersson, Rönnberg 2003; Berglund, Rönnberg 2004; Sierota, Małecka 2004; Thor 2005; Sierota et al. 2007). One of the studied issues is selection of the most efficient at propagation and decomposition of stump wood isolates of $P$. gigantea. The causes for the study are clear at least in the realization of the EU DIR 91/414 and the notification of this species into Annex 1 of the Commission Regulation (EC) 2229/2004.

These are appropriate enzymes that enable fungi to decompose wood (Zeller 1916, after Cartwrigh, Findlay 1951) as one of those first among scientists took up studies of fungi enzymes that decompose wood. In comparison with studies of enzymes in other organisms those of fungi enzymes are not yet sufficiently substantiated. 
The aim of the present study is to define the enzymatic activity of dehydrogenase and phosphatase in the chosen P. gigantea fungi isolates grown on pine wood, as well as assertion and detecting of presence of enzymatic activity that would decompose lignincellulitic bonds in wood; cellulase, laccase and peroxidase. For comparison similar enzymatic activity test was done for pathogen of $H$. annosum sensu lato.

\section{MATERIALS AND METHODS}

The materials of the study were six isolates of $P$. gigantea (marked below as P.g. with an index) and one isolate of $H$. annosum sensu lato as control (Tab. 1).

Sterilized at $120^{\circ} \mathrm{C}$ pine wood pieces of $1 \times 2 \times 3 \mathrm{~cm}$ were placed in dishes containing pure cultures of appropriate isolates and incubated at $24^{\circ} \mathrm{C}$ afterwards. After 30 days the pieces of wood with the mycelium grown on their surface were mechanically crashed (wood mixer, $6000 \mathrm{rpm}$ ) into particles not exceeding $1 \mathrm{~mm}$. Next, the mass was ground in buffer of the appropriate type. Dry mass of each piece of wood was determined upon drying at $105^{\circ} \mathrm{C}$. In samples of appropriate measurement variants dehydrogenase, phosphatase and cellulase were marked.

To mark laccase and peroxidase activities the samples were homogenized in buffer of Tris- $\mathrm{HCl}$ with $\mathrm{pH}=7.5$ in proportion of $1: 10$ and spun at $8000 \mathrm{rpm}$, enzymatic activity and protein were marked in supernatant. The laccase and peroxidase were also marked in liquid cultures of isolates based on mineral nutrient with microelements enriched by $0.5 \%$ glucose with addition of so called ligninsulphanians (paper and cellulose industry waste). This waste in solid state was solved in $0.1 \mathrm{M} \mathrm{NaOH}$ at concentration of $10 \%$ and $1 \mathrm{~cm}^{3}$ of it was added to $100 \mathrm{~cm}^{3}$ of nutrient. The samples were incubated at $26^{\circ} \mathrm{C}$.

Determination of laccase activity. Laccase activity was marked according to Leonowicz and Grzywnowicz (1981) method, $0.5 \mathrm{mM}$ of ethanol solution of syringaldasine was used as substrate. The reaction mixture contained $0.2 \mathrm{~cm}^{3}$ of enzyme (supernatant) $+1.6 \mathrm{~cm}^{3} \mathrm{H}_{2} \mathrm{O}+2 \mathrm{~cm}^{3}$ of citrinian-phosphoran buffer with $\mathrm{pH}=5.0$. The reaction was initiated by adding $0.2 \mathrm{~cm}^{3}$ of syringaldasine solution. Next, absorbency gain was measured at wavelength of $\lambda=525 \mathrm{~nm}$ for 1 minute. The results were converted into activity units, i.e. $\mathrm{U} \cdot \mathrm{min}^{-1}$ according to following pattern:

$(\Delta / \mathrm{min}) /(0.0065 \cdot \mathrm{n} \cdot \mathrm{c})$ with: 0.0065 - absorbency coefficient for syringaldasine; $\mathrm{n}$ - sample thinning; $\mathrm{c}$ - protein concentration in $\mathrm{mg} \cdot \mathrm{cm}^{-3}$.

Table 1

The isolates of $P$. gigantea and $H$. annosum sensu lato used in the experiment

\begin{tabular}{|c|c|c|c|c|}
\hline Isolate & $\begin{array}{c}\text { Localization } \\
\text { (Forest District) }\end{array}$ & $\begin{array}{l}\text { Date of sample } \\
\text { collection }\end{array}$ & $\begin{array}{c}\text { Place } \\
\text { of collection }\end{array}$ & Collection \\
\hline \multicolumn{5}{|c|}{ P. gigantea } \\
\hline$P . g_{._{1}}$ & Jabłonna & 08.06 .2001 & wood of pine stump & \multirow[t]{4}{*}{ Żółciak } \\
\hline$P . g_{{ }_{2}}, P_{g_{\cdot}}$ & Chojnów & 23.10 .2002 & wood of 2 pine stumps & \\
\hline P.g. ${ }_{4}$ P.g. $_{5}$ & Chojnów & 04.11 .2003 & wood of 2 pine stumps & \\
\hline$P . g_{6}$ & Nidzica & 19.11 .2004 & fruit body & \\
\hline \multicolumn{5}{|c|}{ H. annosum sensu lato } \\
\hline H.a. (control) & Pisz & 07.11 .2002 & fruit body & Żółciak \\
\hline
\end{tabular}


Determination of peroxidase activity. Peroxidase activity was marked according to Maehly and Chance (1954) method, modified by Malarczyk (1984). The substrate was prepared by mixing $1 \mathrm{~cm}^{3}$ of $1 \%$ methanol solution of orthodianisidine and $99 \mathrm{~cm}^{3}$ of $0.003 \% \mathrm{H}_{2} \mathrm{O}_{2}$ in $0.1 \mathrm{M}$ octane buffer with $\mathrm{pH}=5.5$. Most often for marking $3.8 \mathrm{~cm}^{3}$ substrate and $0.2 \mathrm{~cm}^{3}$ of enzyme were used. The gain of absorbency was measured at wavelength of $\lambda=460 \mathrm{~nm}$ for 1 minute. The resulting absorbency values were converted into proper activity units: $\mathrm{U} \cdot \mathrm{min}^{-1}$ according pattern:

$(\Delta \mathrm{E} / \mathrm{min}) /(11.3 \cdot \mathrm{n} \cdot \mathrm{c})$ with: 11.3 mole absorbency coefficient for o-dianisidine; $\mathrm{n}$ - sample thinning; $\mathrm{c}$ - protein concentration in $\mathrm{mg} \cdot \mathrm{cm}^{-3}$.

Protein was marked by Lowry et al. (1951) method modified by Schacterle and Pollack (1973).

Determination of cellulase activity. Cellulase activity was analyzed according to Pancholy and Rice (1973) method using carboximethylcellulose (CMC) as a substrate. To $1 \mathrm{~g}$ of crashed mass of wood with mycelium, $0.25 \mathrm{~cm}^{3}$ of toluen was added and 15 minutes later $-5 \mathrm{~cm}^{3}$ of $1 \% \mathrm{CMC}$ solution in octane buffer with $\mathrm{pH}=5.3$. The control ones were those samples with the buffer additive and no substrate. The incubation was run at $30^{\circ} \mathrm{C}$ for $24 \mathrm{hrs}$. On cooling down the samples were filtered and reduction sugars were marked in the filtrate by Samogyi and Nelson (Nelson 1944) method using $1 \mathrm{~cm}^{3}$ of the filtrate and $1 \mathrm{~cm}^{3}$ of Samogyi reagent in the reactive mixture. After $15 \mathrm{~min}$. of warming up in water bath $1 \mathrm{~cm}^{3}$ of Nelson reagent and $2 \mathrm{~cm}^{3} \mathrm{H}_{2} \mathrm{O}$ were added. $20 \mathrm{~min}$. later absorbency was measured at wavelength of $\lambda=520 \mathrm{~nm}$. The results were read from the model graph drawn for glucose and were expressed in $\mu \mathrm{g}$ of glycoside for $1 \mathrm{~g}$ of dry wood mass.

Determination of phosphatase activity. Phosphatase activity of studied isolates was marked according to Tabatabai and Bremner (1969) method with p-nitrophenol phosphorane as a substrate. $4 \mathrm{~cm}^{3}$ of mallein buffer with $\mathrm{pH}=6.5$ and $1 \mathrm{~cm}^{3}$ of substrate (1 tablet of PNP in $20 \mathrm{~cm}^{3}$ buffer) were added to $1 \mathrm{~g}$ wood sample. The substrate was not added to the test sample. The samples were incubated at $37^{\circ} \mathrm{C}$ for 60 min. The enzymatic reaction was stopped in 15 minutes by cooling. After incubation, $4 \mathrm{~cm}^{3}$ of $0.5 \mathrm{M} \mathrm{NaOH}$ buffer was added as well as $1 \mathrm{~cm}^{3}$ of $\mathrm{M} \mathrm{CaCl}_{2}$. Afterwards, the mixture was filtered and filtrate absorbency was marked at wavelength of $\lambda=400 \mathrm{~nm}$. The results were calculated according to pattern: (E·66.43)/dry mass with: 66.43 absorbency coefficient.

Determination of dehydrogenase activity. Dehydrogenase activity was marked according to Thalmann (1968) method with 2,3,5-triphenyltrasol chloride (TTC) as a substrate. $5 \mathrm{~cm}^{3}$ of $1 \%$ solution of TTC in Tris-HCL buffer with $\mathrm{pH}=7.4$ was added to $0.5 \mathrm{~g}$ of wood mass. Only the buffer was added to the test sample. The samples were incubated at $37^{\circ} \mathrm{C}$ for 24 hours. Phormasane ensuing the reduction (TPF) was extracted in $20 \mathrm{~cm}^{3}$ of methyl. The samples were filtered and filtrate absorbency was marked at wavelength of $\lambda=485 \mathrm{~nm}$. The results were calculated according to the model graph drawn for phormasane and were converted into mg of phormasane for $1 \mathrm{~g}$ dry mass of wood for 24 hours.

The markings were made in three parallel repetitions. 


\section{RESULTS}

The analysis performed showed that laccase had been found exclusively for isolate of $H$. annosum sensu lato (Tab. 2). The enzyme was present in case of isolates growing on pine wood pieces as well as of isolates growing in liquid medium containing lignin waste. The highest activity of laccase occurred between the $14^{\text {th }}$ and $21^{\text {st }}$ day of growing. P. gigantea isolates did not show ability to produce laccase except for $P . g_{.}, P . g_{.}$, in case of which trace quantities of laccase were obtained.

All studied isolates showed ability to produce peroxidase (Tab. 3). Cellulase activity differed compared with $H$. annosum, so did phosphatase and dehydrogenase activities (Tabs 4-6). Among enzymes of the isolates in question $P$. gigantea that directly participated in decomposition of lignin laccase enzyme had not been found. The absence of laccase was stated in case of both isolates set on wood and the so called "fresh" ones (trace quantities in case of P.g. P.g..$_{3}$ isolates, 100 times lower than in case of isolate of $H$. annosum).

The highest peroxidase activity was shown by: isolate of $P . g{ }_{6}$ obtained in November 2004 from the fruiting body developing on a pine stump and a set isolate $P . g_{2}{ }_{2}$ obtained in October 2002 from pine stump wood. Isolate P.g. ${ }_{2}$ shows the same share of peroxidase as does isolate H. annosum obtained from the fruiting body in November 2002.

As far as cellulase activity was concerned isolates of $P . g_{.}$and $P . g_{\cdot 2}$ obtained from pine tree stump showed the highest values, whereas $P . g_{.}{ }_{5}$ isolate indicated the lowest values of this parameter.

Table 2

Laccase activity of $P$. gigantea and $H$. annosum isolates

\begin{tabular}{|c|c|c|c|}
\hline \multirow[t]{2}{*}{ Isolate } & \multicolumn{2}{|c|}{$\begin{array}{l}\text { Laccase activity of } P . g . \text { and } H . a \text {. isolates } \\
\text { growing on pine wood }\end{array}$} & \multirow{2}{*}{$\begin{array}{c}\text { Laccase activity of } P . g . \text { and } H . a \text {. isolates } \\
\text { growing in liquid medium } \\
\left.\text { containing lignin waste (in } \mathrm{U} \cdot \mathrm{cm}^{-3}\right)\end{array}$} \\
\hline & $\mathrm{U} \cdot \mathrm{g}^{-1}$ fresh mass & $\mathrm{U} \cdot \mathrm{g}^{-1}$ dry mass & \\
\hline P.g. & 6.976 & 14.310 & 0 \\
\hline P.g. & 0 & 0 & 0 \\
\hline$P . g_{\cdot 3}$ & 5.245 & 11.174 & 0 \\
\hline$P . g_{.4}$ & 0 & 0 & 0 \\
\hline P.g. & 0 & 0 & 0 \\
\hline P.g. & 0 & 0 & 0 \\
\hline H.a. & 590.00 & 1482.785 & 46.882 \\
\hline
\end{tabular}

Table 3

Peroxidase activity of $P$. gigantea and $H$. annosum isolates

\begin{tabular}{|c|c|c|c|}
\hline \multirow[t]{2}{*}{ Isolate } & \multicolumn{2}{|c|}{$\begin{array}{l}\text { Peroxidase activity of } P \text { gigantea and } H \text {. } \\
\text { annosum isolates growing on pine wood }\end{array}$} & \multirow{2}{*}{$\begin{array}{l}\text { Peroxidase activity of } P \text {. gigantea and } H \text {. annosum } \\
\text { isolates growing in liquid medium containing } \\
\text { lignin waste (in } \mathrm{U} \cdot \mathrm{cm}^{-3} \text { ) }\end{array}$} \\
\hline & $\mathrm{U} \cdot \mathrm{g}^{-1}$ fresh mass & $\mathrm{U} \cdot \mathrm{g}^{-1}$ dry mass & \\
\hline$P . g_{.}$ & 1.337 & 2.734 & $7.850 \cdot 10^{-1}$ \\
\hline P.g. & 2.910 & 7.029 & $9.833 \cdot 10^{-1}$ \\
\hline P.g. & 1.246 & 2.654 & $8.989 \cdot 10^{-1}$ \\
\hline$P . g_{\cdot 4}$ & $1.950 \cdot 10^{-1 .}$ & $4.060 \cdot 10^{-1}$ & $1.279 \cdot 10^{-1}$ \\
\hline P.g.5 & $2.828 \cdot 10^{-1}$ & $6.075 \cdot 10^{-1}$ & $2.548 \cdot 10^{-1}$ \\
\hline$P g_{.6}$ & 3.011 & 8.802 & $16.761 \cdot 10^{-1}$ \\
\hline H.a. & 2.903 & 7.296 & $41.919 \cdot 10^{-1}$ \\
\hline
\end{tabular}


Table 4

Cellulase activity of $P$. gigantea and $H$. annosum isolates

\begin{tabular}{|c|c|c|c|c|}
\hline \multirow[t]{2}{*}{ Isolate } & \multicolumn{2}{|c|}{$\mu$ g glucose $\cdot \mathrm{g}^{-1}$ fresh mass } & \multicolumn{2}{|c|}{$\mu \mathrm{g}$ glucose $\cdot \mathrm{g}^{-1}$ dry mass } \\
\hline & Repetition & Average & Repetition & Average \\
\hline$P \cdot g_{\cdot_{1}}$ & $\begin{array}{l}2015.0 \\
2054.0 \\
1950.0\end{array}$ & 2006.33 & $\begin{array}{l}4133.33 \\
4213.33 \\
4000.00\end{array}$ & 4115.55 \\
\hline$P . g_{\cdot_{2}}$ & $\begin{array}{l}1976.0 \\
2059.2 \\
2080.0\end{array}$ & 2038.00 & $\begin{array}{l}4772.95 \\
4973.91 \\
5024.15\end{array}$ & 4923.67 \\
\hline$P . g_{3}$ & $\begin{array}{l}1911.0 \\
1586.0 \\
1716.0\end{array}$ & 1737.67 & $\begin{array}{l}4071.15 \\
3378.78 \\
3655.73\end{array}$ & 3701.89 \\
\hline$P . g_{\cdot}$ & $\begin{array}{l}1092.0 \\
1313.0 \\
1066.0\end{array}$ & 1157.0 & $\begin{array}{l}2273.58 \\
2733.71 \\
2219.45\end{array}$ & 2408.91 \\
\hline$P . g_{5}$ & $\begin{array}{l}455.0 \\
390.0 \\
117.0\end{array}$ & 320.0 & $\begin{array}{l}977.44 \\
837.81 \\
251.34\end{array}$ & 688.86 \\
\hline$P g_{.}$ & $\begin{array}{l}1183.0 \\
1079.0 \\
1105.0\end{array}$ & 1122.33 & $\begin{array}{l}3458.05 \\
3154.05 \\
3230.05\end{array}$ & 3280.72 \\
\hline H.a. & $\begin{array}{l}1833.0 \\
1508.0 \\
1755.0\end{array}$ & 1698.0 & $\begin{array}{l}4606.69 \\
3789.90 \\
4410.66\end{array}$ & 4269.08 \\
\hline
\end{tabular}

Table 5

Phosphatase activity of $P$. gigantea and $H$. annosum isolates

\begin{tabular}{|c|c|c|c|c|}
\hline \multirow{2}{*}{ Isolate } & \multicolumn{2}{|c|}{$\mu \mathrm{g} \mathrm{p}-\mathrm{PNP} \cdot \mathrm{g}^{-1}$ fresh mass $\cdot \mathrm{h}^{-1}$} & \multicolumn{2}{|c|}{$\mu \mathrm{g}$ p-PNP $\cdot \mathrm{g}^{-1} \mathrm{dry}_{\text {mass }} \cdot \mathrm{h}^{-1}$} \\
\hline & Repetition & Average & Repetition & Average \\
\hline$P \cdot g_{\cdot{ }_{1}}$ & $\begin{array}{l}136.12 \\
134.72 \\
136.38\end{array}$ & 135.74 & $\begin{array}{l}279.22 \\
276.75 \\
279.75\end{array}$ & 278.44 \\
\hline$P g_{\cdot 2}$ & $\begin{array}{l}25.04 \\
26.71 \\
27.17\end{array}$ & 26.31 & $\begin{array}{l}60.49 \\
64.50 \\
65.63\end{array}$ & 63.54 \\
\hline$P . g_{.3}$ & $\begin{array}{l}127.63 \\
128.14 \\
127.08\end{array}$ & 127.62 & $\begin{array}{l}272.99 \\
271.90 \\
270.73\end{array}$ & 27187 \\
\hline$P . g_{._{4}}$ & $\begin{array}{l}132.00 \\
138.77 \\
134.45 \\
\end{array}$ & 135.07 & $\begin{array}{l}274.83 \\
288.92 \\
279.93 \\
\end{array}$ & 281,23 \\
\hline$P g_{._{5}}$ & $\begin{array}{l}132.73 \\
133.39 \\
146.01 \\
\end{array}$ & 137.38 & $\begin{array}{l}285.13 \\
286.55 \\
313.66 \\
\end{array}$ & 295.11 \\
\hline$P . g_{6}$ & $\begin{array}{l}104.76 \\
101.51 \\
101.97 \\
\end{array}$ & 102.75 & $\begin{array}{l}306.23 \\
296.73 \\
298.07 \\
\end{array}$ & 300.34 \\
\hline H.a. & $\begin{array}{l}142.23 \\
135.92 \\
141.89\end{array}$ & 140.01 & $\begin{array}{l}357.45 \\
341.59 \\
356.59\end{array}$ & 351.88 \\
\hline
\end{tabular}

The highest activity as regards phosphatase formation showed the isolate of $H$. annosum; the lowest - P.g. ${ }_{2}$ isolate. Similar values as regards phosphatase formation were shown by P.g. ${ }_{1}, P . g .{ }_{4}$ and P.g. ${ }_{5}$ isolates. The highest dehydrogenase activity along with $H$. annosum was shown by the isolate of $P . g .{ }_{5}$ and the lowest by P.g. ${ }_{6}$ isolate obtained from the fruiting body. 
Table 6

Dehydrogenase activity of $P$. gigantea isolates and $H$. annosum isolates

\begin{tabular}{|c|c|c|c|c|}
\hline \multirow[t]{2}{*}{ Isolate } & \multicolumn{2}{|c|}{ mg TPF $\cdot g^{-1}$ fresh mass $\cdot 24 \mathrm{~h}^{-1}$} & \multicolumn{2}{|c|}{ mg TPF $\cdot \mathrm{g}^{-1}$ dry mass $\cdot 24 \mathrm{~h}^{-1}$} \\
\hline & Repetition & Average & Repetition & Average \\
\hline$P g_{{ }_{1}}$ & $\begin{array}{l}25.65 \\
17.99 \\
21.86\end{array}$ & 21.84 & $\begin{array}{l}52.63 \\
36.90 \\
44.85\end{array}$ & 44.80 \\
\hline$P g_{{ }_{2}}$ & $\begin{array}{l}15.41 \\
15.08 \\
14.68\end{array}$ & 15.06 & $\begin{array}{l}37.22 \\
36.44 \\
35.46\end{array}$ & 36.37 \\
\hline$P . g_{3}$ & $\begin{array}{l}19.44 \\
15.25 \\
22.67\end{array}$ & 19.12 & $\begin{array}{l}41.42 \\
32.48 \\
48.29 \\
\end{array}$ & 40.74 \\
\hline$P . g_{4}$ & $\begin{array}{l}19.36 \\
20.17 \\
16.14\end{array}$ & 18.56 & $\begin{array}{l}40.31 \\
41.99 \\
33.60\end{array}$ & 38.63 \\
\hline$P g_{{ }_{5}}$ & $\begin{array}{l}25.82 \\
24.20 \\
21.78\end{array}$ & 23.93 & $\begin{array}{l}55.47 \\
51.99 \\
46.79\end{array}$ & 51.42 \\
\hline P.g. ${ }_{6}$ & $\begin{array}{c}7.26 \\
8.07 \\
10.48\end{array}$ & 8.60 & $\begin{array}{l}21.22 \\
23.59 \\
30.63\end{array}$ & 25.15 \\
\hline H.a. & $\begin{array}{l}18.56 \\
24.20 \\
26.62\end{array}$ & 23.13 & $\begin{array}{l}46.64 \\
60.82 \\
66.90\end{array}$ & 58.12 \\
\hline
\end{tabular}

\section{FINAL REMARKS}

Laccase is responsible for toxic phenols oxidation. The phenols are exuded by plants as a defensive reaction to fungi infection. It participates in lignin oxidation as well as in degradation and detoxification of antifungal phenols in plant tissues (Mayer, Harel 1979; Mayer 1987; Mayer, Staples 2002). It can oxidize many substrates including mono-, di-(o-di- and p-di-), and tri-phenols. The absence of that enzyme in the wood being decomposed by $P$. gigantea isolates confirms the idea that $P$. gigantea is not a pathogenic organism, like fungus $H$. annosum sensu lato that show high activity of phenoloxidase and no peroxidase activity (Sierota, Miseikyte 2000). In joint pure cultures of $H$. annosum sensu lato and $P$. gigantea, on malt extract agar medium with guaiacol $H$. annosum mycelium causes discoloration of substrate into intense cherry and dark brown color as a result of guaiacol oxidation by phenoloxidase (Boidin 1951; Havličková, Rypáček 1957). Laccase activity has been reported in mycelial and rhizomorphs extracts of Armillaria that is - from pathogenic organisms as well (Kaarik 1965; Marsh, Wargo 1989).

Peroxidase catalyzes the oxidation of phenols by hydrogen peroxide $\left(\mathrm{H}_{2} \mathrm{O}_{2}\right)$ and is non-specific for phenols. It was detected in exudates from Armillaria rhizomorphs (Mallett, Colotelo 1984). It makes one of the agents that determine pathogenic feature of Armillaria (Robene-Soustrade et al. 1992). In roots and bark of the butt of spruce roots ridden by Armillaria significantly increased peroxidase activity was affirmed in comparison with healthy trees (Feiler, Tesche 1991).

No similarities were found between diversified cellulase isolate activity and place or time of sample taking. Fungi can lose their abilities for enzyme production when cultured for long time (Szklarz et al. 1989).

Sierota and Miseikyte (2000) indicated that with overgrowth of pine tree roots by mycelium $P$. gigantea and secretion of enzymes (cellulase, phosphatase, 
dehydrogenase, peroxidase) the tree became attractive for pine weevil imago for its females to lay eggs (second generation of pine weevil).

\section{REFERENCES}

Berglund M., Rönnberg J. 2004. Effectiveness of treatment of Norway spruce stumps with Phlebiopsis gigantea at different rates of coverage for the control of Heterobasidion. For. Path. 34 (4): 233.

Boidin J. 1951. Recherche de la tyrosinase et de la laccase chez les Basidiomycetes ou culture pour millieux differentieles. Rev. Mycol. Fr. 16: 28-42.

Cartwright K. St. G., Findlay W. P. K. 1951. Rozkład i konserwacja drewna. PWRiL.

Feiler S., Tesche M. 1991: Peroxidaseaktivitat von Fichte bei Hallimaschbefall bzw. unter Immissionseinfluss - Versuch einer Diferenzierung der Stressindikation. Flora 185 (1): 47-54.

Havličková V., Rypáček V. 1957. Enzymy dřevokazných hub I. Zjištváni oxydačnich exoenzymů. Česká Mycologie 2: 96-102.

Kaarik A. 1965. Identification of the mycelia of wood-decay fungi by the oxidation reactions with phenolic compounds. Studia Forestalia Suecica 31: 1-80.

Korhonen K., Lipponen K., Bendz M., Johansson M., Ryen I., Venn K., Seiskari P., Niemi M. 1994. Control of Heterobasidion annosum by stump treatment with Rotstop, a new commercial formulation of Phlebiopsis gigantea. (In:) M. Johansson, J. Stenlid (eds). Proceedings of $8^{\text {th }}$ IUFRO International Conference on Root and Butt Rots. 9-16 August 1993, Swedish University of Agricultural Sciences, Uppsala: 657-685.

Lakomy P. 2001. Comparison on scots pine (Pinus sylvestris L.) stump treatment with PG and rotstop based on Phlebiopsis gigantea (Fr.: Fr.) Jülich. Forestry 4: 139-146.

Leonowicz A., Grzywnowicz K. 1981. Quantitative estimation of laccase forms in some white-rot fungi using syringaldazine as a substrate. Enz. Microbiol. Technol. 3: 55-58.

Lowry J. O. H., Rosenbrough N. J., Farr A. L., Randal P. J. 1951. Protein measurement with folin phenol reagent. J. Biol. Chem. 193: 265-275.

Maehly A. C., Chance B. 1954. The assay of catalases and peroxidases. (In:) D. Glik (ed.). Methods of Biochemical Analysis. Vol. 1. Interscience Publishers, New York: 357-366.

Malarczyk E. 1984. Substrate - induction of veratric acid O-demethylase in Nocardia sp. Acta Biochem. Polon. 31: 383-395.

Mallet K. I., Colotelo N. 1984. Rhizomorph exudates of Armillaria mellea. Can. J. Microb. 30: 12471252.

Marsh S. F., Wargo P. M. 1989. Phenol oxidases of five Armillaria biospecies. Phytopathology 79: 1150.

Mayer A. M. 1987. Polyphenol oxidases in plants - recent progress. Phytochemistry 26 (1): 1-20.

Mayer A. M., Harel E. 1979. Polyphenol oxidases in plants. Phytochemistry 18: 193-215.

Mayer A. M., Staples R. C. 2002. Laccase: new functions for an old enzyme. Phytochemistry 60 (6): 551565.

Nelson N. 1944. A photometric adaptation of the Samogyi method for the determination of glucose. J. Biol. Chem. 153: 375-380.

Nicolotti G., Gonthier P., Varese G. C. 1999. Effectiveness of some biocontrol and chemical treatments against Heterobasidion annosum on Norway spruce stumps. Eur. J. For. Path. 29 (5): 339.

Pancholy S. K., Rice E. L. 1973. Soil enzymes in relation to old field succession: amylase, cellulase, intertase, dehydrogenase and urease. Soil Sci. Soc. Amer. Proceedings 37: 47-50.

Pettersson M., Rönnberg J. 2003. Effect of thinning and Phlebiopsis gigantea stump treatment on the growth of Heterobasidion parviporum inoculated in Picea abies. Scandin. J. For. Research 18 (4): 362-367.

Pratt J. E., Niemi M., Sierota Z. H. 2000. Comparison of three products based on Phlebiopsis gigantea for the control of Heterobasidion annosum in Europe. Biocontrol Sci. Tech. 10: 467-477.

Rishbeth J. 1951. Obsevations on the biology of Fomes annosus, with particular reference to East Anglian pine plantaqtions. III. Natural and experimental infection of pines and some factors affecting severity of the disease. Ann. Bot. 15: 221-247.

Rishbeth J. 1959. Dispersal of Fomes annosus Fr. and Peniophora gigantea (Fr.) Massee. Trans. Brit. Mycol. Soc. 42: 243-260. 
Rishbeth J. 1963. Stump protection against Fomes annosus. III. Inoculation with Peniophora gigantea. Ann. Appl. Biol. 52: 63-77.

Robene-Soustrade I., Lung Escarmant B., Bono J. J., Taris B. 1992. Identification and partialcharacterization of an extracellular manganese-dependent peroxidase in Armillaria ostoyae and Armillaria mellea. Eur. J. For. Pathol. 22 (4): 227-236.

Schacterle G. R., Pollack R. L. 1973. A simplified method for the quantitative assay of small amounts of protein in biological material. Analyt. Biochem. 51: 654-655.

Sierota Z. 1995. Rola grzyba Phlebiopsis gigantea (Fr.: Fr.) Jülich w ograniczaniu huby korzeni w drzewostanach sosny zwyczajnej (Pinus sylvestris L.) na gruntach porolnych. Pr. Inst. Bad. Leśn. 810: 1-180.

Sierota Z. H., Małecka M. 2004. Modyfikacja biologicznej metody ochrony przed hubą korzeni i porównanie kosztów z metodą tradycyjną. Sylwan 4: 34-39.

Sierota Z. H., Małecka M., Pratt J. E. 2007. Eindämmung des Wurzelpilzes Heterobasidion annosum in Beständen mit Gemeiner Kiefer in Ackeraufforstungen. Archiv für Forstwesen und Landschaftsökologie 41: 29-35.

Sierota Z., Miseikyte R. 2000. Wektory przenoszenia infekcji grzyba Heterobasidion annosum (Fr.) Bref. w odnowieniach stanowiących drugie pokolenie lasu na gruncie porolnym. Sprawozdanie końcowe. Instytut Badawczy Leśnictwa, Warszawa.

Szklarz G. D., Antibus R. K., Sinsabaugh R. L., Linkins A. E. 1989. Production of phenol oxidases and peroxidases by wood-rotting fungi. Mycologia 81 (2): 234-240.

Tabatabai M. A., Bremner J. M. 1969. Use of p-nitrophenyl phosphate for assay of soil phosphatase activity. Soil Biol. Biochem. 1: 301-307.

Thalmann A. 1968. Zur Methodik der Bestimmung der Dehydrogenase-Aktivität in Boden mittels Triphenyltetrazoliumchlorid (TTC). Landwirtschaftliche Forschung 21 (1): 249-258.

Thor M. 2005. Heterobasidion root rot in Norway spruce: modelling incidence, control efficacy and economic consequences in Swedish foresty. Doctoral thesis. Swedish University of Agricultural Sciences, Uppsala.

Westlund A., Nohrstedt H.-Ö. 2000. Effects of stump-treatment substances for root-rot control on ground vegetation and soil properties in a Picea abies forest in Sweden. Scandinavian Journal of Forest Research 15 (5): 550-560.

Zeller S. M. 1916. Physiology of Lenzites sepiaria. Annals Missouri Botanical Garden 3: 439-512.

\section{Aktywność enzymatyczna wybranych izolatów Phlebiopsis gigantea}

\section{Streszczenie}

Celem badań było określenie aktywności enzymatycznej dehydrogenaz i fosfataz u wybranych izolatów grzyba $P$. gigantea hodowanych na drewnie sosnowym, jak również stwierdzenie obecności oraz oznaczenie aktywności enzymów rozkładających połączenia ligninocelulozowe w drewnie - celulazy oraz lakazy i peroksydazy. Dla porównania, wykonano analogiczne testy aktywności enzymatycznej grzybni patogena $-H$. annosum sensu lato.

Przeprowadzone analizy wykazały, że lakaza była wykrywana w hodowlach izolatu grzyba $H$. annosum. Największą aktywność peroksydazy wykazywały: izolat P.g. ${ }_{6}$ pozyskany w listopadzie 2004 r. z owocnika rozwijającego się na pniaku sosnowym oraz pasażowany izolat P.g. ${ }_{2}$ pozyskany w październiku 2002 r. z drewna pniaka sosnowego. U izolatu P.g. ${ }_{2}$ stwierdzono podobny udział peroksydazy, jak u izolatu $H$. annosum, pozyskanego z owocnika w listopadzie 2002 r. Pod względem aktywności celulolitycznej wyróżniały się izolaty P.g. ${ }_{1}$ i P.g. ${ }_{2}$ pozyskane z drewna pniaka sosnowego, najmniejsze zaś wartości tego wskaźnika wykazywał izolat $P . g_{5}$. Nie stwierdzono przy tym zbieżności między zróżnicowaną aktywnością celulolityczną izolatów, a miejscem czy terminem pobrania próbek.

Największą aktywnością pod względem tworzenia fosfatazy wykazywał izolat H. annosum, najmniejszą zaś izolat $P . g_{2}$. U izolatów: $P . g .{ }_{1}, P . g{ }_{4}{ }_{4}$ oraz P.g. ${ }_{5}$ odnotowano podobne wartości fosfatazy Najwyższą aktywnością dehydrogenazy, obok izolatu $H$. annosum, odznaczał się izolat $P . g .{ }_{s}$ a najmniejszą zaś izolat P.g. ${ }_{6}$ pozyskany z owocnika. 